\title{
KOMUNIKASI POLITIK KIAI \\ DALAM PEMILIHAN UMUM TAHUN 2019
}

\author{
Khoirul Mushthofa Misyuniarto \\ Universitas Islam Negeri Sunan Ampel Surabaya \\ oiktok@gmail.com
}

\begin{tabular}{l}
\hline Article Info \\
\hline Article history: \\
Received 18 Februari 2020 \\
Accepted 16 Maret 2020 \\
Published 10 April 2020 \\
\hline
\end{tabular}

Keyword:

Komunikasi Politik, Kiai, Pemilihan Umum, Pondok Pesantren

\begin{abstract}
This study examines the political communication strategy carried out by Kiai as a boarding school caretaker in the General Election. The purpose of this study is to describe the political communication strategy carried out by Kiai Syafik Rofi'i, caretaker of the Salafiyah Syafi'iyah Islamic Boarding School in Bangkalan Regency, East Java Province in the 2019 General Election.

This study uses a qualitative descriptive method with a case study approach. The results showed that the political communication strategy being implemented was political negotiation among kiai in Islamic boarding schools in Bangkalan Regency. In addition, political communication uses the strategy of a campaign winning team or success team, and also uses the media as a channel for delivering messages to provide understanding and influence public opinion.

Penelitian ini meneliti strategi komunikasi politik yang dilakukan oleh Kiai sebagai pengasuh Pondok Pesantren dalam Pemilihan Umum. Tujuan penelitian ini adalah mendeskripsikan strategi komunikasi politik yang dilakukan oleh Kiai Syafik Rofi'i, pengasuh Pondok Pesantren Salafiyah Syafi'iyah di Kabupaten Bangkalan Provinsi Jawa Timur dalam Pemilihan Umum 2019.

Penelitian ini menggunakan metode deskriptif kualitatif dengan pendekatan studi kasus. Hasil penelitian menunjukkan, bahwa strategi komunikasi politik yang dijalankan adalah negosiasi politik di kalangan kiai di pondok pesantren di Kabupaten Bangkalan. Di samping itu, komunikasi politik menggunakan strategi tim pemenangan kampanye atau tim sukses, dan juga menjadikan media sebagai saluran penyampaian pesan untuk memberikan pengertian dan mempengaruhi opini publik.
\end{abstract}

Copyright (C) 2020 Jurnal Ilmu Komunikasi

\section{Editorial Office:}

Program Studi Ilmu Komunikasi, Fakultas Dakwah dan Komunikasi, UIN Sunan Ampel Surabaya. Jl. Ahmad Yani 117 Surabaya, Jawa Timur, Indonesia.

Email: jurnalilkom@uinsby.ac.id 


\section{Pendahuluan}

Kehidupan manusia dikelilingi oleh berbagai macam komunikasi, sikap alamiah dari seorang manusia adalah dia akan selalu melakukan aktifitas komunikasi di kehidupan sehari-harinya. Salah satunya adalah komunikasi politik. Politik yang dimaksud disini bukan hanya mengikuti alur dari partai politik saja, akan tetapi dari sikap kita mempertimbangkan baik dan buruk, untung dan rugi itu juga sudah merupakan bagian dari politik.

Komunikasi dan politik, banyak ditemukan dalam elemen-elemen masyarakat yang akan bersikap aktif dalam dunia politik secara luas yang cakupannya mengenai kekuasaan. Komunikasi politik sendiri merupakan pemaknaan dari dari suatu fungsi yang selalu ada dalam setiap sistem politik sehingga terbuka kemungkinan bagi para ilmuwan untuk memperbandingkan berbagai sistem politik dengan latarbelakang budaya yang berbeda. ${ }^{1}$

Pengertian dari Komunikasi Politik sendiri kadang mengalami pembiasan sebab bisa diartikan melalui dua konsep keilmuan yang berbeda. Bisa melalui pandangan ilmu komunikasi dan juga bisa melalui pandangan ilmu politik. Dalam penggabungan keduanya ditemukanlah jalan tengah yang menjembatani kedua disiplin ilmu ini melalui komunikasi politik yaitu studi komunikasi politik selalu identik dengan komunikasi publik dan juga biasa dijumpai pada musim pemilu sebagai komunikasi kampanye.

${ }^{1}$ Ardial, Komunikasi Politik, (Jakarta: Indeks, 2009), 4.
Melihat definisi yang sudah dipaparkan secara jelas tentang komunikasi politik, ada hal yang juga harus disinggung dalam pembahasan komunikasi politik itu sendiri yaitu strategi. Komunikasi politik pasti akan menggunakan strategi tertentu untuk mencapai tujuan yang ingin diwujudkan. Menerapkan komunikasi politik berarti haruslah memiliki strategi yang sudah disiapkan sejak awal memulainya. Hakikat dari strategi dalam komunikasi politik adalah keseluruhan keputusan kondisional pada saat ini tentang tindakan yang akan dijalankan guna untuk mencapai tujuan politik pada masa depan. ${ }^{2}$

Komunikasi politik dilaklukan di manapun berada, termasuk kehidupan pesantren, tidak sedikit dari para kiai yang merupakan pengasuh dari pondok pesantren tersebut yang memutuskan untuk terjun ke dunia politik dengan terlibat dalam pemilihan umum. Hal itu dilakukan karena kiai sudah mendapatkan predikat ketokohan agama yang kuat sehingga yakin dengan modal yang dimilikinya itu bisa dan mampu untuk menjadi bagian dari orang-orang yang terlibat dalam pemilihan umum. Ketokohan dari seorang komunikator politik sangatlah memiliki peran yang besar dalam berhasil tidaknya komunikasi politik dalam mencapai sasaran dan tujuannya, termasuk yang dilakukan oleh kiai apabila telah menjatuhkan pilihan untuk terlibat dalam pemilihan umum.

Salah satu contoh nya adalah keterlibatan dari pengasuh pondok

\footnotetext{
${ }^{2}$ Ardial, Komunikasi, 73.
} 
pesantren Salafiyah Syafi'iyah yang memilih untuk terjun ke dunia politik. Sebagai seorang kiai beliau melebarkan sayap dan memilih untuk terjun ke dunia politik. Bukan hanya sebatas sebagai pengasuh dari pondok pesantren Salafiyah Syafi'iyah saja. Dalam keterlibatannya di dalam pemilu, pastinya akan memakai strategi-strategi yang nantinya bisa menunjang keputusannya untuk terlibat di dalam dunia perpolitikan.

Pada kehidupan masyarakat luas, peran kiai sendiri sangatlah kental akan nuansa agamis. Biasanya, seorang kiai juga akan dipatuhi ucapan dan arahannya oleh masyarakat luas khususnya oleh masyarakat Kabupaten Bangkalan yang juga dikenal dengan sebutan kota santri. Kepercayaan masyarakat yang begitu tinggi terhadap kiai dan didukung potensinya memecahkan berbagai problem sosio-psikis-kultural-politik-religius menyebabkan kiai menempati posisi kelompok elit dalam struktur sosial dan politik di masyarakat. ${ }^{3}$

Seringkali kiai jauh lebih dihormati dari pada pejabat yang ada dilingkungan sekitar. Sebab, banyak yang mempercayai petuah-petuah yang diucapkan oleh kiai kadang memiliki daya pikat yang luar biasa, hal ini mempermudah para kiai untuk menggalang dukungan atau massa dari berbagai kalangan. Bukan hanya dari kalangan pesantren yang diasuhnya saja akan tetapi dari kalangan masyarakat awam yang menghormati kiai tersebut.

3 Mujammil Qomar, Pesantren: Dari Transformasi Metodologi Menuju Demokratisasi Institusi, (Jakarta: Erlangga, tt.), 23.
Pentingnya peneliti ini karena berkembangnya zaman semakin terang dan jelas bahwa praktik politik kekuasaan sudah mendarah daging di kalangan masyarakat secara luas tidak terkecuali kalangan kiai yang memilih terjun ke dunia politik.

Banyak sekali ditemui kiai atau pengasuh pondok pesantren yang akhirnya memilih jalan politik sebagai pilihan hidupnya di samping menjadi seorang kiai yang dihormati masyarakat. Banyak proses dan juga strategi berjalannya komunikasi politik yang masih menjadi rahasia dan tidak banyak diketahui oleh khalayak luas, khususnya di daerah Bangkalan, Madura. Proses komunikasi serta strategi tersebut apa memang menjadi rahasia untuk diketahui hanya di kalangan kiai saja atau bisa dikonsumsi oleh khalayak umum. Fenomena inilah yang mengantarkan peneliti untuk mengkaji lebih dalam dan melihat temuan nyata dilapangan tentang hal tersebut.

\section{Kajian Pustaka}

\section{Komunikasi Politik Kiai dan Pesantren}

Komunikasi politik merupakan bagian yang tak terpisahkan dari ilmu komunikasi. Sebab keduanya saling melengkapi antara yang satu dengan yang lain. Definisi komunikasi politik sendiri adalah suatu komunikasi yang diarahkan kepada pencapaian suatu pengaruh sedemikian rupa, sehingga masalah yang dibahas oleh jenis kegiatan komunikasi ini, dapat 
mengikat semua warganya melalui suatu sanksi yang ditentukan bersama. ${ }^{4}$

Dalam komunikasi politik juga terdapat hal yang memang sangat mendukung dalam terjadinya beberapa unsur di atas. Penguatan ketokohan politik adalah upaya dari penyusunan strategi komunikasi politik. Dari penguatan itu maka akan muncul citra politik yang tergambarkan dan terbangun dari tokoh politik. Citra politik itu sendiri adalah gambaran seseorang yang terkait dengan politik (kekuasaan, kewenangan, otoritas, konflik, dan consensus) citra politik juga berkaitan dengan pendapat umum, karena pada dasarnya pendapat umum politik terwujud sebagai konsekuensi dari kognisi komunikasi politik. $^{5}$

Kiai adalah pemimpin non formal sekaligus pemimpin spiritual, dan posisinya sangat dekat dengan kelompokkelompok masyarakat lapisan bawah di desa-desa. Sebagai pemimpin di masyarakat, sosok kiai memiliki Jemaah komunitas dan massa yang diikat oleh hubungan keguyuban yang erat dan ikatan budaya petrenalistik. Petuah-petuahnya selalu didengar, diikuti, dan dilaksanakan oleh Jemaah, komunitas, dan massa yang dipimpinnya. ${ }^{6}$

Pesantren sendiri memiliki makna sebagai tempat mendapatkan pelajaran tentang keilmuan yang meliputi ilmu-ilmu agama, biasnya terfokuskan pada kitabkitab yang dikaji oleh santri yang dijelaskan oleh seorang kiai

4 Asep Saeful Muhtadi, Komunikasi Politik Indonesia : Dinamika Islam Politik Pasca-Orde Baru, (Bandung: PT. Remaja Rosdakarya), 30.

\section{Proses Komunikasi Politik}

Proses komunikasi politik biasanya terfokus bagaimana pesan yang akan disampaikan oleh kelompok yang memiliki kepentingan seperti partai politik, lembaga negara atau bahkan politisi sekalipun akan melalui saluran yang sudah dipilih. Saluran ini biasanya dijadikan media dalam penyampaian pesannya baik secara langsung (kampanye) atau tidak langsung (televisi, radio, koran). Dari media itu nantinya akan disalurkan kepada targetnya yaitu masyarakat atau publik luas.

Proses komunikasi yang diterapkan melalui komunikasi politik tradisional boleh dan sah-sah saja digunakan, akan tetapi kurang ideal sebab hanya komunikasi satu arah. Seperti efektifnya komunikasi pada umumnya, baiknya komunikasi itu berjalan secara dua arah dalam artian akan ada feedback yang dihasilkan dari komunikasi itu sendiri.

Gambaran di atas merupakan proses komunikasi yang di dalamnya terdapat timbal balik diantara orang-orang yang terlibat. Anak panah yang saling berhubungan tersebutlah yang menandakan bahwa proses komunikasi politik di atas telah terjadi timbal balik di dalamnya. Bentuk komunikasi dapat dilihat dari beberapa cara dan seberapa tersebarnya pesan tersebut dapat bergantung pada besar kelompok tersebut dan cara penyampaiannya. Kelompokkelompok di atas akan bersaing satu sama lain agar mendaptakn hati dar masyarakat

${ }^{5}$ Muchlis, Komunikasi Politik, (Surabaya: Sunan Ampel Press, 2014), 33.

${ }^{6}$ Qomar, Pesantren :Dari Transformasi, 29. 
luas dan pesan yang disampaikan bisa di dengar. $^{7}$

Beberapa penjelasan di atas bisa memberikan bukti bahwa komunikasi politik posisi nya memang sangatlah penting dalam mengendalikan sikap dari masyarakat luas dalam menyikapi suatu hal dalam kehidupan bernegara.

\section{Strategi Komunikasi Politik}

Hakikat strategi komunikasi dalam komunikasi politik adalah seluruh keputusan kondisional pada saat ini tentang tindakan yang akan dijalankan guna mencapai tujuan pada masa depan. Proses komunikasi politik tidak hanya melihat bagaimana strategi komunikasi itu dijalankan, akan tetapi melihat tokoh politik dalam artian masyarakat akan melihat figur yang berbicara atau yang menyampaikan pesan politik itu. Ardial dalam bukunya mengemukakan beberapa strategi komunikasi politik yang biasa diterapkan dalam komunikasi politik, yaitu ${ }^{8}$ :

a. Keberadaan Pemimpin Politik

Pemimpin bisa dikatakan sebagai ujung dari pergerakan komunikasi politik, sebab komando akan ada di tangan pemimpin politik. Akan tetapi dalam pembagian atau stratifikasi komunikasi politik, adanya keberadaan pemimpin politik akan dipecah menjadi dua bagian, yang pertama adalah kalangan elit dan yang kedua adalah massa rakyat. Dua tingkatan tersebut sudah menjadi rumus yang kekal dalam

7 Thomas Tokan Pureklolon, Komunikasi Politik : Mempertahankan Integritas Akademisi, Politisi dan Negarawan, (Jakarta: PT. Gramedia Pustaka Utama, 2016), 10. pembagian kekuasaan, dimana yang pertama akan menjadi yang membuat dan berkuasa akan suatu kebijakan sedangkan yang kedua akan menjadi bagian yang mematuhi apa yang telah diputuskan oleh kalangan yang pertama.

Aktor politik akan selalu berperan dalam adanya pemimpin politik. Biasanya pemimpin politik akan menjadi aktor politik dalam suatu komunikasi politik, akan tetapi tidak semua aktor politik akan memiliki peran dalam menjadi pemimpin politik. Pemimpin atau elit adalah strata tertinggi yang bisa menentukan arah gerak dari suatu sistem.

b. Merawat Ketokohan dan Menetapkan Kelembagaan

Hal ini merupakan langkah yang kedua dalam strategi komunikasi politik. Setelah dimunculkannya sosok pemimpin politik, selanjutnya adalah bagaimana meneruskan dan menjaga ketokohan dari seorang pemimpin politik tersebut. Banyak hal bisa menjadi dukungan untuk terus merawat ketokohan yang sudah dimunculkan, di antaranya memperhatikan isi pesan yang disampaikan agar terus mendapatkan simpati dari rakyat, menggunakan lembaga atau partai politik yang nantinya bisa membantu ketika melakukan komunikasi politik dan yang terakhir memilih media yang nantinya juga bakal menjadi senjata

8 Anwar Arifin, Komunikasi Politik: Paradigma-Teori-Aplikasi-Strategi \& Komunikasi Politik di Indonesia, (Jakarta: Balai Pustaka, 2003), 145 
untuk terus memberikan framing yang bagus tentang diri tokoh tersebut.

Dalam komunikasi politik, masyarakat akan lebih menaruh rasa hormat dan simpatinya dalam hal retorika atau pidato politik kepada siapa yang berbicara (aktor) dari pada melihat apa yang disampaikannya (pesan) tersebut. ${ }^{9}$ Hal itu sudah menjadi cukup bukti bahwa dalam proses komunikasi politik sangatlah penting kedudukan dari tokoh politik.

c. Menciptakan Kebersamaan

Perlu adanya kebersamaan dalam proses komunikasi politik. Hal ini sangat sederhana dalam memahaminya, manusia cenderung lebih menghargai ketika siapa atau apa yang sedang ada di depannya cenderung sama atau mirip dengan dirinya. Itu sudah menjadi sifat dasar dari manusia, jika itu sudah dilakukan maka akan timbul rasa saling menghargai dan saling mendukung. Maka dari itu sangatlah perlu apabila dalam strategi komunikasi politik memunculkan rasa kebersamaan.

Rasa kebersamaan yang telah dimunculkan akan menjadi sugesti tersendiri dikalangan masyarakat, sebab akan ada rasa kepemilikan yang itu juga akan membantu dalam proses berjalannya komunikasi politik. Langkah yang harus dilakukan dalam menciptakan suasana kebersamaan ini di mulai dari memahami khalayak (rakyat), menyusun pesan yang akan

\footnotetext{
${ }^{9}$ Ardial, Komunikasi Politik, 80.
}

disampaikan, memilih media dalam menyampaikan pesan.

d. Negosiasi

Proses komunikasi pada umumnya sangatlah fleksibel. Akan mudah apabila komunikasi ini saling dipahami oleh pelaku komunikasi dan akan sangat sulit apabila di antara pelaku komunikasi tidak saling mengetahui akan apa yang dikomunikasikan. Dalam komunikasi politik sendiri, negosiasi adalah hal sangat mendasar dan akan selalu muncul, sebab dalam komunikasi politik banyak penawaran-penawaran dan juga sejalan dengan kepentingan. Oleh sebab itu, negosiasi ini tidak bisa dilepaskan dari strategi komunikasi politik.

Negosiasi akan menjadi kunci dari berhasilnya komunikasi atau perundingan. Apabila terjadi ketidak sepemahaman antara pelaku komunikasi politik maka baiknya diambil langkah negosiasi untuk membicarakan kemungkinan yang akan dilanjutkan pada tahap yang lebih tinggi.

\section{e. Membangun Konsensus}

Langkah strategi yang lain dalam komunikasi politik adalah membangun konsensus antara politikus dari partai yang sama ataupun dengan politikus dari partai yang berbeda. ${ }^{10}$ Biasanya politikus yang melakukan konsensus ini akan menggunakan model komunikasi

\footnotetext{
${ }^{10}$ Arifin, Komunikasi Politik, 182.
} 
interaktif sesuai dengan kebutuhan yang ada dalam proses yang diinginkan.

Proses pembangunan konsensus ini ada kaitannya dengan kebersamaan (apabila satu partai) sehingga memiliki rasa kepemilikan yang sama atau juga bisa memiliki hubungan dengan tahapan negosiasi (apabila beda partai) sehingga apa yang sudah diupayakan tersebut akan berjalan dengan sesuai rencana. Hal yang sangat mendasar dalam strategi komunikasi politik di tahap ini adalah harus ada keterbukaan sehingga akan menimbulkan rasa kepercayaan dianatar aktor politik yang berhubungan, selain itu harus memahami seni berkompromi antara yang satu dengan yang lain.

\section{Metode Penelitian}

Dalam penelitian ini menggunakan pendekatan kualitatif deskriptif, yaitu penelitian yang bermaksud untuk memahami tentang fenomena yang telah dialami oleh subyek penelitian. Misalnya mengenai perilaku, motivasi, dan lain sebagainya. ${ }^{11}$

Teknik pengumpulan data juga menggunakan wawancara mendalam dengan tujuan mencari informasi yang bisa mendukung kegiatan penelitian, dokumentasi yang dilakukan untuk memberikan bukti hasil asli dalam proses pencarian data, dan menggunakan data rekaman yang bisa membantu peneliti untuk menganalisis data yang diperoleh.

11 Lexy J.Moleong, Metode Penelitian Kualitatif, (Bandung: Remaja Rosdakarya, 2008), 84.

\section{Hasil Dan Pembahasan}

Pondok Pesantren Salafiyah Syafi'iyah adalah salah satu lembaga pendidikan Islam non formal yang ada di Kabupaten Bangkalan. Tepatnya berada di kelurahan Pangeranan, Kecamatan Bangkalan. Dikatakan sebagai lembaga non formal sebab pondok pesantren ini tidak memiliki sekolah formal layaknya jenjang Sekolah Dasar sampai dengan Sekolah Menengah Atas, hanya saja di lingkungan Pondok Pesantren ini terdapat lembaga pendidikan Taman Kanak-Kanak saja.

Pengasuh pondok pesantren ini sendiri adalah seorang Kiai yang namanya cukup dikenal di Bangkalan, beliau adalah $\mathrm{KH}$. Moh. Syafik Rofi'i namanya cukup dikenal di Bangkalan bukan tanpa alasan, sebab dalam perjalanan hidupnya beliau juga pernah menjabat sebagai wakil Bupati Bangkalan pada periode 2008-2013. Selain itu beliau juga merupakan ketua takmir Masjid Agung Bangkalan, maka tak heran bila nama beliau dikenal oleh banyak masyarakat Bangkalan.

Disamping kesibukannya sebagai seorang politikus, KH. Syafik Rofi'i tidak melupakan tugas lainnya yaitu mendesain bagaimana proses belajar mengajar santri yang ada di Pesantren yang dimilikinya, dengan fokus pada pembelajaran ilmu agama dan kitab-kitab klasik. Jika pendidikan formalnya di arahkan untuk bersekolah di lembaga formal Negeri. Santri di pondok ini bermacam-macam tingkatan, mulai dari tingkatan SMP 
sampai Perguruan Tinggi juga terdapat di Pondok Pesantren Salafiyah Syafi'iyah.

\section{Strategi Komunikasi Politik Kiai dalam Pemilihan Umum 2019}

Dalam hal komunikasi politik, ada langkah yang biasa digunakan oleh individu yang terlibat dalam komunikasi politik. Langkah itu biasa nya dinamakan dengan strategi komunikasi politik. Strategi komunikasi politik sendiri merupakan upaya untuk menjalankan tujuan utama, biasanya setiap individu yang terlibat memiliki cara tersendiri atau kadang juga menggunakan cara yang biasanya juga digunakan oleh orang lain.

"Namanya juga ngabdi sama kiai mas, ya saya kasih kabar aja sama orang rumah. Orang tua dan saudara-saudara saya upayakan untuk nyoblos pak kiai. Gak masalah orang rumah mas, pasti mendukung juga" 12

Jika sebelumnya dikatakan bahwa KH. Syafik Rofi'i mengungkapkan bahwa beliau tidak menggunakan pesantren nya untuk penunjang politik praktis dalam karir politikya, akan tetapi kenyatan dilapangan mengungkapkan fakta atas dasar hormat seorang santri kepada kiainya lah yang mengantarkan santri akan bersikap spontan untuk mendukung keterlibatan kiai dalam pemilihan umum. Sikap hormat dan menjunjung nilai patuh terhadap guru yang mendorong seorang santri akan bersikap demikian kepada siapa yang dihargainya.
Strategi komunikasi lain yang juga dilakukan adalah dengan bernegosiasi dengan para kelompok-kelompok yang ada di masyarakat dengan harapan mendapatkan ruang di masyarakat sehingga nantinya kelompok-kelompok tersebut mendukung secara penuh untuk proses pencalonan beliau. Komunikasi yang dilakukan dengan cara masuk kedalam lingkungan yang ada pada masyarakat atau juga kelompok terkuat lainnya dalam strata kehidupan di Kabupaten Bangkalan, yaitu yang identik dengan kehidupan kiai dan pondok pesantren. Maka tidak heran apabila dalam komunikasinya, ada peran dari negosiasi atau terjalinnya kerjasama dengan pihak-pihak pondok pesantren lainnya yang ada di kabupaten Bangkalan.

Strategi komunikasi politik ini juga sejalan dengan strategi komunikasi yang ada pada bagian definisi konsep yang sudah dijelaskan di atas. Bagaimana keberadaan tokoh politik ini sejajar dengan keberadaan dari pimpinan pondok pesantren. Sebab kedudukannya dalam kehidupan masyarakat Bangkalan, keberadaan sosok kiai dianggap lebih sacral dan diagungkan serta dipatuhi tutur kata dan perbuatannya. Maka dari itu, informan berusaha membangun relasi dengan tokoh-tokoh yang memiliki latar belakang yang sama yaitu pengasuh pondok pesantren lainnya, selain itu informan juga berusaha memasuki kalangan kelompok yang ada di masyarakat yang tujuannya

\footnotetext{
${ }^{12}$ Hasil wawancara dengan informan M. Iqbal Alawy pada tanggal 02 November 2019.
} 
memunculkan rasa kebersamaan supaya juga mendapat simpati dari masyarakat yang di dekatinya.

Membangun kebersamaan itu juga merupakan suatu strategi yang dibangun dan diciptakan oleh KH. Syafik Rofi'i sebab dianggapnya bahwa apabila kebersamaan itu dibangun maka semua akan bekerja dengan ikhlas den penuh dengan kejujuran, dan itu yang diharapkan hadir dalam iklim komunikasi politik yang diciptakan di dalam tim kampanyenya. Akan tetapi segala upaya belum tentu membuahkan hasil, kembali lagi pandangan dari khalayak umum lah yang memntukan bagaimana hasil dari pertarungan pemilihan umum di suatu Negara.

Walau telah menggunakan langkah dalam proses komunikasi politik dengan sistematis dan juga menjalankan stretegi yang menjanjikan namun tidak ada jaminan dalam hal politik. Tidak ada kepastian yang bisa membuat orang atau kontestan merasa tenang. Walaupun dalam wawancara awal disebutkan hubungan kiai tidak bisa dilepaskan dari politik, namun pada prakteknya bisa saja seorang kiai tidak memenangkan pertarungan sebab memang politik adalah hal yang dinamis. Semua pasti memiliki kejutan tersendiri yang membuat apa yang telah disusun dengan rapi bisa saja rusak hanya karena sesuatu hal yang berbeda dengan ekspektasi yang dibangun.

\section{Komunikasi Politik Kiai dalam Pemilihan Umum 2019}

Proses komunikasi politik yang dilakukan oleh kiai Syafik Rofi'i dalam keterlibatannya di pemilihan umum sangat kompleks dan tersusun rapi dari bawah hingga ke atas, sebab peneliti di sini menemukan jawaban dari informan tentang proses komunikasi yang dijalankan. Tanpa melihat hasil akhir dari pemilihan umum 2019 menang atau kalah, kajian utama dalam penelitian ini adalah bagaimana proses komunikasi politik. Dikatakan sangat detail sebab informan membangun kepercayaan dan dukungan dari hal yang paling kecil mulai dari keluarga hingga konteks yang meluas yaitu antar pondok pesantren.

Jika dilihat dari latar belakang $\mathrm{KH}$. Syafik Rofi'i yang seorang kiai sekaligus politikus, bisa dikatakan sangat mendukung beliau dalam karir politiknya. Ini terbukti ketika beliau menceritakan bagaimana perjalanan dan pencapaian tertingginya dalam karir politik yang sudah lama digelutinya. Setelah menanyakan itu dalam sesi wawancara, peneliti maju lebih jauh dalam hal strategi komunikasi politik yang digunakan oleh seorang kiai dalam pemilihan umum yang telah diikutinya.

Penguatan komunikasi interpersonal dalam keluarga juga menjadi poin mendasar dalam proses komunikasi politik yang dijalankan oleh KH. Syafik Rofi'i dalam keterlibatannya di pemilihan umum. Proses komunikasi yang dibangun dari dasar lingkup yang paling mendasar yaitu penguatan dalam keluarga, disatu sisi ada faktor ketokohan yang kuat dalam diri $\mathrm{KH}$. Syafik Rofi'i beliau juga menjalankan proses komunikasi politik dengan sangat terstruktur dan sitematis, dimulai dukungan dari keluarga inti kemudian meluas ke keluarga yang lebih besar. Sebab 
rata-rata pondok pesantren yang ada di Bangkalan banyak yang memiliki keterikatan hubungan darah diantara para pengasuhnya.

Disamping itu juga menggunakan media massa dan online juga dianggap sangat penting apabila dilihat dari apa yang disampaikan oleh informan yang kedua ini. Melihat fungsi dari komunikasi massa sendiri dalam mendukung proses komunikasi politik adalah dapat membentuk pendapat dari khalayak umum. Proses dari pendapat umum ini biasanya adanya pemberian stimulus dari komunikator kepada khalayak kemudian nantinya akan menghasilkan suatu penilaian dari khalayak atau masyarakat luas yang menerima pesan tersebut.

Proses komunikasi politik yang dilakukan oleh KH. Syafik Rofi'i telah menggunakan proses komunikasi yang dibangun secara sistematis mulai dari penguatan tokoh, penggalangan dukungan hingga proses komunikasi secara langsung dengan masyarakat. Begitu juga dengan strategi komunikasi yang dilakukan juga mengguna kan banyak hal yang mungkin tidak banyak diketahui oleh masyarakat umum, seperti menjalin negosiasi politik dengan pengasuh pondok pesantren lainnya. Dua hal tersebut adalah upaya yang dilakukan oleh KH. Syafik Rofi'i untuk berkompetisi menghadapi pertarungan dalam Pemilihan Umum yang diikuti di Dapil 14.

Peneliti akan mencoba menganalisa lebih dalam tentang proses komunikasi dan strategi komunikasi politik di setiap Kabupaten yang ada di Pulau Madura. Peneliti merasa hal ini harus dilakukan sebab hasil perolehan suara yang telah diperoleh oleh KH. Syafik Rofi'i menarik untuk diketahui. Berikut hasil analisa mengenai proses komunikasi politik dan strategi komunikasi politik yang dilakukan oleh KH. Syafik Rofi'i di seluruh Kabupaten yang ada di Pulau Madura.

\begin{tabular}{|c|c|c|c|c|c|}
\hline \multirow[b]{2}{*}{ Nama } & \multicolumn{4}{|c|}{ Jumlah Suara } & \multirow[b]{2}{*}{$\begin{array}{c}\text { Jumlah } \\
\text { Akhir }\end{array}$} \\
\hline & $\begin{array}{l}\text { Bang } \\
\text { kalan }\end{array}$ & $\begin{array}{l}\text { Sam } \\
\text { pang }\end{array}$ & $\begin{array}{l}\text { Pame } \\
\text { kasan }\end{array}$ & $\begin{array}{c}\text { Sume } \\
\text { nep }\end{array}$ & \\
\hline $\begin{array}{c}\text { KH. Syafik } \\
\text { Rofi'i }\end{array}$ & 5.700 & 455 & 3.461 & 13.509 & 23.125 \\
\hline
\end{tabular}

Tabel 1.1. Hasil Penghitungan Suara KH. Syafik Rofi'i Dapil 14

Berdasarkan data yang telah di dapatkan oleh peneliti ini akan dilakukan pembahasan mengenai proses komunikasi politik dan juga strategi yang dilakukan di tiap Kabupaten. Sebab pada perolehan di setiap Kabupaten juga terdapat jarak perolehan yang cukup signifikan perbedaannya. Berikut hasil analisa peneliti dari data perolehan suara di setiap Kabupaten:

a. Kabupaten Bangkalan

Kabupaten Bangkalan adalah kota kelahiran dan juga tempat KH. Syafik Rofi'i lebih dikenal oleh masyarakat, akan tetapi hasil yang diperoleh cukup mengejutkan, sebab hasil perolehan suara yang didapat hanya 5.700 suara.

Proses Komunikasi yang dilakukan oleh KH. Syafik Rofi'i tidaklah berbeda dari proses komunikasi politik yang dijalankan pada Kabupaten lain yang ada di Kabupaten lainnya. Proses komunikasinya meliputi pemasangan 
baliho disudut kota serta menguatkan figur ketokohan melalui media sosial. Melihat sosok KH. Syafik Rofi'i yang juga merupakan kiai yang cukup dihormati di kabupaten bangkalan, maka proses komunikasi politik yang dijalankan juga melakukan negosiasi politik dengan pondok pesantren lainnya yang ada di Bangkalan, tujuannya adalah untuk menggalang massa dalam dukungannya terhadap dirinya.

Sosialisasi politik dengan dikonsep pengajian juga merupakan salah satu proses dan juga strateginya untuk mendapatkan simpati dari masyarakat. Hal itu juga dikatakan oleh informan bahwa dengan cara tersebut cukup banyak meraup dukungan, sebab melihat antusiasme dari masyarakat cukuplah antusias, khususnya pada daerah yang ada di pedesaan. Akan tetapi tidak bisa diterapkan pada masyarakat kota, sebab keinginan untuk memberikan kepercayaan kepada msayarakat sipil biasa masih kuat. Hal lain yang juga dijalankan adalah masuk dalam lingkungan masyarakat Blater atau kalangan prema yang ada di Bangkalan. Sebab strata sosial tersebut masih banyak dijumpai di Bangkalan. Melalui kesenian sandur juga sudah dilakukan untuk mendapatkan simpati dari masyarakat.

Analisa dari peneliti mengenai jumlah suara yang di dapat dengan komunikasi politik yang dilakukan bisa dikatakan kurang maksimal, sebab jumlah tersebut masih dibawah standart melihat figur ketokohan yang ada pada diri KH. Syafik Rofi'i. peneliti menganggap bahwa pamor atau kekuatan ketokohan dari $\mathrm{KH}$. Syafik Rofi'i mulai luntur dan banyak masyarakat Bangkalan yang ingin adanya perubahan kepemimpinan dengan memberikan kepercayaan pada masyarakat sipil. Hal tersebut juga tidak dibantah oleh informan.

Hal ini berdasarkan data yang ada dalam penghitungan yang berhasil memenangkan salah satu calon dengan jumlah mencapai 42.429 suara. Latar belakang dari calon tersebut bukanlah kalangan kiai melainkan kalangan sipil biasa, terlebih lagi adalah seorang wanita.

b. Kabupaten Sampang

Dari peroleh suara diseluruh kabupaten yang ada pada seluruh Kabupaten yang ada, Kabupaten Sampang adalah daerah pemilihan yang sangat memprihatinkan. Sebab dari suara yang diperoleh hanya berjumlah 455 suara saja. Menurut hasil wawancara dengan informan memang disebutkan bahwa Kabupaten Sampang adalah Kabupaten tersulit untuk dijamah. Sebab selain adanya rasa penghormatan yang tinggi kepada putra daerah, ada juga hal yang membuat sangat sulit mendapatkan suara di kabupaten Sampang yaitu kurangnya antusias dari masyarakat.

Sejak awal komunikasi politik yang dijalankan memang tidak maksimal. Menurut informan, ketika diadakannya sosialisasi sangat sedikit masyarakat yang hadir, bahkan bisa 
dikatakan hanya kalangan relawan dan tim sukses saja yang menghadiri acara sosialisasi itu. Hal tersebut disebabkan karena kurangnya intensitas kehadiran atau terjun langsungnya KH. Syafik Rofi'i ke masyarakat Sampang. Padahal sebenarnya itu juga sangat mempengaruhi kualitas kedekatan dengan masyarakat yang nantinya akan memilih dirinya.

Peneliti berkesimpulan tentang komunikasi politik yang dijalankan di Kabupaten Sampang ini kurang intens dan kurang efektif. Baik dari komunikator politik dan juga masyarakat. Akhirnya itu terbukti dari hasil yang diperoleh yang bisa dikatakan sangatlah kecil. Adanya keinginan masyarakat untuk mengusung calon dari putra daerah juga yang menjadi halangan tersendiri untuk mendapatkan kemenangan besar di Kabupaten Sampang. Salah satu calon lainnya dengan nama Alyadi yang merupakan pemenang pemilihan umum legislatdif DPRD Jawa Timur adalah putra daerah Sampang, maka tidak heran bila perolehan suaranya sangatlah besar dan mengalahkan calon lainnya.

c. Kabupaten Pamekasan

Perolehan suara di Kabupaten Pamekasan tidak terlalu jauh beda dengan Kabupten Bangkalan, walaupun caranya tidak terlalu maksimal jika dibandingkan antar dua Kabupaten tersebut. Kehidupan masyarakat di Kabupaten Pamekasan tidaklah jauh beda dengan masyarakat
Sampang, hanya saja lebih terbuka terhadap calon yang bukan dari daerah tersebut. Sebab ketika diadakan komunikasi politik melalui sosialisasi, masih ada beberapa masyarakat yang antusias untuk mengahdiri acara tersebut. Itu bisa dilihat dari jumlah total suara yang di dapat, yaitu dengan jumlah 3.461 suara.

Pendekatan di kalangan kiai juga dilakukan di Kabupaten Pamekasan ini, hanya saja memang kurang cukup menjadi senjata untuk mengalahkan calon legilatif dari daerah asli kabupaten tersebut. Melihat data wawancara yang didapatkan dengan informan, memang diakui bahwa kawasan yang masih sangat minim untuk dijamah dan dimasuki masyarakatnya adalah Kabupaten Sampang dan Pamekasan, itu diakui sebab memang letak geografis dari dua kabupaten tersebut yang masih pedalaman dan tradisional.

Analisa peneliti pada perolehan suara dikabupaten ini akhirnya mengerucut pada perlunya pendekatan yang intens, hal itu dilakukan untuk memberikan figur ketokohan di Kabupaten lain jadi tidak hanya terfokus pada daerah asal dari $\mathrm{KH}$. Syafik Rofi'i.

d. Kabupaten Sumenep

Kabupaten Sumenep adalah Kabupaten yang sangat mengejutkan dalam perolehan suara. Walau letak geografisnya yang berada di ujung pulau Madura, akan tetapi dalam penyumbangan suara merupakan 
daerah yang menyumbangkan suara terbanyak kepada KH. Syafik Rofi'i dengan jumlah total 13.509 suara. Itu tidak lepas dari strategi yang digunakan yaitu melakukan pendekatan intens dengan kiai yang merupakan pengasuh pondok pesantren besar, yaitu Pondok Pesantren Al-Amin. Hubungan kekeluargaan yang dekat yang akhirnya menghantarkan KH. Syafik Rofi'i mendapatkan suara yang melebihi daerah asal yaitu Bangkalan.

Strategi lainnya adalah adanya upaya untuk mendapatkan dukungan dari kalangan seniman dengan melakukan pendekatan terhadap paguyuban-paguyuban seniman yang terdapat di Kabupaten Sumenep. Itu menjadi poin atau kelebihan tersendiri bagi Kh. Syafik Rofi'i. begitu juga ketika adanya sosialisasi politik, lebih banyak peserta yang hadir dibandingkan dengan masyarakat di daerah lain, itu tak lepas dari digandengnya kiai yang cukup dikenal di Kabupaten Sumenep yaitu KH. Muhammad Tidjani Jauhari, itu menyebabkan banyak masyarakat yang menghormati dan memilih untuk mengikuti intruksi dari kiai yang dihoormatinya.

Pada komunikasi politik disini selain memperkuat komunikasi secara individual, perlu memang adanya gerakan kerjasama dengan tokoh terkenal di daerah setempat sehingga ada bantuan moral dari tokoh tersebut. Proses memahami budaya juga telah diterapkan sehingga hasil yang diperoleh tidak mengecewakan seperti di Kabupaten lainnya.

Dari penjelasan mengenai perolehan suara yang ada diseluruh kabupaten yang ada di Madura mengindikasikan bahwa sosok kiai bukan lagi menjadi satu-satunya yang memang harus dipilih dan diagungkan. Ini bisa dilihat dari hasil yang telah diperoleh oleh KH. Syafik Rofi'i yang belum diberikan kemenangan dalam pemilihan umum tahun 2019. Kurangnya komunikasi yang intens juga merupakan analisa dari peneliti, selain itu adanya strategi yang digunakan terkesan tradisional. Itu merupakan kesulitan yang memang nyata dan mengakibatkan kekalahan dalam pemilihan umum tahun 2019.

Peran dari khalayak sangatlah menentukan, sesuai dengan konsep proses komunikasi politik yang dikemukakan oleh Lasswell, bagaimana kedudukan khalayak adalah penentu dari suatu keputusan atau hasil dari dilakukannya suatu komunikasi. Selain itu, masyarakat sudah mulai tidak menghiraukan latar belakang yang ada pada kiai yang terjun pada dunia politik, sebab politik tetaplah hal yang privasi dalam penentuan suaranya. Hingga pada akhirnya hasil perolehan dari KH. Syafik Rofi'i yang hanya 23.125 tidak cukup untuk memenangkan pemilihan umum. KH. Syafik Rofi'i hanya berada diperingkat 6 dari 12 calon legislatif yang diusung oleh PKB. Jatah kursi yang ada di DPRD Jawa Timur pun hanya 2 sehingga tidak bisa menjadikannya anggota Dewan DPRD Jawa Timur. 


\section{Kesimpulan}

Mengenai proses komunikasi politik, telah dijelaskan bahwa memang tahapan dari proses komunikasi politik yang dilakukan mengarah pada penguatan karakter ketokohan dan kemudian peneliti menggunakan analisis dari teori Lasswell sehingga tergambar jelas bagaimana proses itu dijalankan. Kemudian pada tahapan strategi komunikasi politik terdapat upaya menyampaikan pesan menggunakan caracara yang masuk dalam bagian masyarakat, termasuk juga adanya negosiasi politik di kalangan kiai di pondok pesantren.

Strategi komunikasi lainnya yang juga digunakan adalah memunculkan rasa kebersamaan dalam tim pemenangan kampanye atau tim sukses dan juga menjadikan media sebagai saluran menyampaikan pesan untuk memberikan dan mempermainkan opini publik sehingga menghasilkan suatu penguatan figur ketokohan dari seorang KH. Syafik Rofi'i yang dalam hal ini terlibat aktif dalam pemilihan umum legislatif. Akan tetapi pada kenyataan nya dalam pertarungannya KH. Syafik Rofi'i tidak berhasil memenangkan kontestasi pemilihan umum tersebut.

Jadi bisa disimpulkan bahwa walau telah menyusun secara sistematis proses dan strategi yang digunakan, tetapi pada kenyataannya peran khalayak lah yang menentukan proses menang tidaknya. Apabila dilihat dengan teori nomer dua yang dipakai oleh peneliti maka masih belum adanya kepercayaan akan sosok KH. Syafik Rofi'i untuk memenangkan kontestasi pemilihan umum 2019. Walaupun memang posisi kiai tidak akan bisa dilepaskan dengan keberlangsungan politik yang ada di Indonesia.

\section{Daftar Pustaka}

Ardial. Komunikasi Politik. Jakarta: Indeks, 2009.

Arifin, Anwar. Komunikasi Politik: Paradigma-Teori-Aplikasi-Strategi \& Komunikasi Politik di Indonesia. Jakarta: Balai Pustaka, 2003.

Burhan, Bungin. Metode Penelitian Sosial. Surabaya: Airlangga University Pres, 2010.

Hafied, Cangara. Komunikasi Politik : Konsep, Teori dan Strategi. Jakarta: PT. Raja Grafindo Persada, 2011.

Hasil wawancara dengan informan $\mathrm{M}$. Iqbal Alawy pada tanggal 02 November 2019

Moleong, Lexy J. Metode Penelitian Kualitatif. Bandung: Remaja Rosdakarya, 2008.

Morissan. Teori Komunikasi Individu Hingga Massa. Jakarta: Kencana, 2013.

Muchlis. Komunikasi Politik. Surabaya: Sunan Ampel Press, 2014.

Qomar, Mujammil. Pesantren: Dari Transformasi Metodologi Мепији Demokratisasi Institusi. Jakarta: Erlangga, tt.

Saeful, Asep Muhtadi. Komunikasi Politik Indonesia : Dinamika Islam Politik Pasca-Orde Baru. Bandung: PT. Remaja Rosdakarya, 2008.

Stephen, Littlejohn W\& Foss Karen A. Teori Komunikasi. Jakarta: Penerbit Salemba Humanika, 2009.

Tokan, Thomas Pureklolon. Komunikasi Politik: Mempertahankan Integritas Akademisi, Politisi dan Negarawan. Jakarta: PT. Gramedia Pustaka Utama, 2016. 